\title{
THE INFLUENCE OF LIMING THE RANKER SOIL TYPE WITH FLY- ASH OF KOSOVO POWERPLANTS, ON CHEMICAL AND PHYSICAL PROPERTIES
}

\author{
Aleksandar Djikic ${ }^{372}$ \\ Sasa Barac ${ }^{373}$ \\ Nebojsa Gudzic ${ }^{374}$ \\ Miroljub Aksic ${ }^{375}$ \\ Milan Biberdzic ${ }^{376}$ \\ Tatjana Jaksic ${ }^{377}$ \\ Ivica Mihajlovic ${ }^{378}$
}

https://doi.org/10.31410/itema.2018.1097

\begin{abstract}
Increased acidity is very often a limiting factor for decreased soil fertility and unfavorable chemical and physical soil properties. Various materials can be used for liming the acidic soils such as natural ones (ground limestone or slag lime) as well as industrial waste (i.e. saturation silt). Fly-ash from Kosovo power-plants appears as a waste material after burning in the reactors. The material itself causes serious environmental consequences, especially because it is hardly remediated, due to its chemical and physical properties. Since 1963, Kosovo power plants have formed huge fly-ash dumps of very poor remediation ability, with over than 200.000mt of fly-ash. But, despite of its low remediation ability, the material has properties to be used in liming of acidic soils. The fact that fly-ash from Kosovo power-plants is alkaline, with a relatively high content of $\mathrm{CaO}$ and $\mathrm{CaCO}$, it is recommended as a material which can be successfully used in melioration of acidic soils. In our experiment we used the soil type Ranker, as a typical acidic soil from the mountain regions of Kosovo. Quantities of applied material for liming were 1, 3, and 5 mtha-1, calculated on volume of experimental pots of 4 liters. The obtained results recommend the applied liming material as the proper material for use in liming the Ranker soil type. Significant improvements of $p H$ and other chemical properties have been reached, after the experiment, as well as better stability of soil structure.
\end{abstract}

Keywords: Fly-ash, Ranker, liming, acid soil

\section{Introduction}

$\mathrm{F}$ ly-ash (Electrofilters ash, EF ash) occurs as a result of coal combustion in power-plants poses a serious environmental problem. On the one hand, the ash landfill is deposited on agricultural land, which excludes them from agricultural production, and on the other hand EF ash is subject to eolation, which affects the quality of the environment kilometers around (Resulović, 1988.).

\footnotetext{
${ }^{372}$ University of Pristina, Faculty of Agriculture, KosovskaMitrovica - Lesak, Serbia

${ }^{373}$ University of Pristina, Faculty of Agriculture, KosovskaMitrovica - Lesak, Serbia

${ }^{374}$ University of Pristina, Faculty of Agriculture, KosovskaMitrovica - Lesak, Serbia

${ }^{375}$ University of Pristina, Faculty of Agriculture, KosovskaMitrovica - Lesak, Serbia

${ }^{376}$ University of Pristina, Faculty of Agriculture, KosovskaMitrovica - Lesak, Serbia

${ }^{377}$ University of Pristina, Faculty of Life Science, Kosovska Mitrovica, Serbia

${ }^{378}$ School of Agriculture, Lesak, Serbia
} 
Coal burning in Kosovo's power plants has been carried out since 1963 with the opening of the thermal power plant, Kosovo „A“ power $449 \mathrm{MW}$, which was particularly intensified by the opening of another power plant Kosovo „B“" power $580 \mathrm{MW}$ in 1980. During all the operations of Kosovo's thermal power-plants, ash dumps have been formed, which involve 2,000 hectares of arable land. Moreover, in EF ash the dust fraction prevails, which allows its eolation, thus adversely affecting the environment and agricultural crops. According to the recurrability of ash deposits, they are hardly recurrable (Cairney, 1987.), and therefore pose an additional problem in the living environment of the area. (Šmit, 1988). The cause of poor recurrence lies also in the chemical properties of EF ash, both in terms of high alkalinity and in terms of cementation of the surface layer of landfills (Đikić et al., 1995.).

However, the fact that $\mathrm{EF}$ is an alkaline reaction with a very high content of $\mathrm{CaO}$, it is recommended to research its application in alkaline acid calcification.

The calculation is a pedomeliorative measure of repair of acidic soils and the materials to which it is made may be different: $\mathrm{CaO}, \mathrm{CaCO} 3$, dolomit, saturation sludge and others. This study recommends EF ash as a calibration material, given its chemical and physical properties.

The available amount of ash is quite sufficient to consider its commercial use in the future.

\section{Materials and Methods}

The research used the pedological map of the AP of Kosovo and Metohija (Institut „Jaroslav Černi“", 1974.), as well as the soil type Ranker from Lesak county on the Kopaonik mountain Serbia. The chemical properties of ash were analyzed by standard methods (Black et al. 1965.). The experiment was carried out as an indoor one, in experimental pots of volume of $4 \mathrm{dm}^{3}$. Soil moisture was maintained on the level of retention capacity $(33 \mathrm{kPa})$.

The characteristics of the EF ash are presented in table 2, as well as the properties of the soil used in the experiment (table 1). The use of EF ash was $10 \mathrm{mtha}^{-1}$ (dosage 1), $30 \mathrm{mtha}^{-1}$ (dosage 2) and $50 \mathrm{mtha}^{-1}$ (dosage 3), with control without the use of calcification agent. Compost is used as an additional fertilizer, for the purpose of achieving better solubility of the calcification agent (Banasova, 1989, Flaig, 1981). The culture of cultivation in this regard was grass mixture. Grass mixture was chosen as the typical culture of a given area.

The results were presented in Table 3. Statistic analyze was done accordingly, and presented as well.

\section{Results of research and discussion}

The soil used in the survey was taken in Lesak k.r. on the Kopaonik mountain in Serbia and by type belongs to humic-silicate soil type -Ranker. The chemical properties of the soil treated in the sample are shown in the table 1. 
Table 1. Chemical properties of soil in the experiment

\begin{tabular}{|c|c|c|c|c|c|c|c|c|}
\hline $\begin{array}{c}\text { Dept } \\
h\end{array}$ & $\begin{array}{c}\mathrm{pH}_{\mathrm{H} 2} \\
\mathrm{o}\end{array}$ & $\mathrm{pH}_{\mathrm{KCl}}$ & $\begin{array}{c}\text { Humus } \\
(\%)\end{array}$ & $\mathrm{N}(\%)$ & $\begin{array}{c}\mathrm{P} 2 \mathrm{O} 5 \\
(\mathrm{mg} / 100 \mathrm{~g} \\
)\end{array}$ & $\begin{array}{c}\mathrm{K} 2 \mathrm{O} \\
(\mathrm{mg} / 100 \mathrm{~g}\end{array}$ & $\mathrm{CaCO} 3$ & $\begin{array}{c}\mathrm{T}-\mathrm{S} \\
(\mathrm{meq} / 100 \mathrm{~g})\end{array}$ \\
\hline $0-10$ & 4,7 & 4,1 & 8,2 & 0,41 & 5,5 & 27 & 0,7 & 32,5 \\
\hline $\begin{array}{c}10- \\
22\end{array}$ & 5,0 & 4,3 & 6,5 & 0,35 & 2,4 & 25 & 1,0 & 40,2 \\
\hline $\begin{array}{c}23- \\
56\end{array}$ & 5,2 & 4,2 & 4,0 & 0,21 & 2,0 & 28 & 1,0 & 38,4 \\
\hline
\end{tabular}

As seen from the table shown, the soil in the experiment is very acidic with high humus content, with a somewhat higher amount of phosphorus than expected because it was agricultural land. The content of potassium is moderate. Hydrolytic acidity, shows levels of necessity of liming the soil.

The characteristics of EF ash are shown in the table 2.

Table 2. Chemical properties of fly-ash from Kosovo powerplants

\begin{tabular}{|c|c|c|c|c|c|c|c|}
\hline Depth & $\mathrm{pH}_{\mathrm{H} 2 \mathrm{O}}$ & $\mathrm{pH}_{\mathrm{KCl}}$ & $\begin{array}{c}\mathrm{CaO} \\
(\%)\end{array}$ & $\mathrm{Na}(\%)$ & $\begin{array}{c}\mathrm{P} 2 \mathrm{O} 5 \\
(\mathrm{mg} / 100 \mathrm{~g})\end{array}$ & $\begin{array}{c}\mathrm{K} 2 \mathrm{O} \\
(\mathrm{mg} / 100 \mathrm{~g})\end{array}$ & $\mathrm{CaCO} 3$ \\
\hline $0-10$ & 10,52 & 10,0 & 47,5 & 1,22 & 8,5 & $>40$ & 15,2 \\
\hline $11-20$ & 9,11 & 8,85 & 41,5 & 1,14 & 5,4 & $>40$ & 18,4 \\
\hline $20-30$ & 10,00 & 9,21 & 37,2 & 0,90 & 3,0 & $>40$ & 9,2 \\
\hline $30-40$ & 9,85 & 9,45 & 45,0 & 1,10 & 2,0 & $>40$ & 8,5 \\
\hline
\end{tabular}

The influence of liming material on amelioration of Ranker with fly-ash is statistically analyzed, and the results are presented in Table 3.

Table 3. ANOVA of the obtained results

\begin{tabular}{|c|c|c|c|c|c|c|}
\hline & & Sum of Squares & df & Mean Square & $\mathrm{F}$ & Sig. \\
\hline \multirow[t]{3}{*}{$\mathrm{pH}(\mathrm{H} 2 \mathrm{O})$} & Between Groups & ,996 & 2 & \multirow{3}{*}{$\begin{array}{l}\text {,498 } \\
016\end{array}$} & \multirow[t]{3}{*}{32,000} & \multirow[t]{3}{*}{, 001} \\
\hline & Within Groups & ,093 & 6 & & & \\
\hline & Total & 1,089 & 8 & & & \\
\hline \multirow[t]{3}{*}{$\mathrm{pH}(\mathrm{KCl})$} & Between Groups & ,667 & 2 & ,333 & \multirow[t]{3}{*}{27,273} & \multirow[t]{3}{*}{,001 } \\
\hline & Within Groups & ,073 & 6 &, 012 & & \\
\hline & Total & ,740 & 8 & & & \\
\hline \multirow[t]{3}{*}{ Humus (\%) } & Between Groups & ,336 & 2 & , 168 & \multirow[t]{3}{*}{5,393} & \multirow[t]{3}{*}{,046 } \\
\hline & Within Groups & , 187 & 6 &, 031 & & \\
\hline & Total &, 522 & 8 & & & \\
\hline \multirow[t]{3}{*}{$\mathrm{N}(\%)$} & Between Groups &, 002 & 2 & ,001 & \multirow[t]{3}{*}{3,207} & \multirow[t]{3}{*}{, 113 } \\
\hline & Within Groups & ,002 & 6 &, 000 & & \\
\hline & Total &, 004 & 8 & & & \\
\hline \multirow[t]{3}{*}{$\mathrm{P} 2 \mathrm{O} 5(\mathrm{mg} / 100 \mathrm{~g})$} & Between Groups &, 016 & 2 & ,008 & \multirow[t]{3}{*}{, 084} & \multirow[t]{3}{*}{920} \\
\hline & Within Groups &, 553 & 6 & ,092 & & \\
\hline & Total & ,569 & 8 & & & \\
\hline \multirow[t]{3}{*}{$\mathrm{K} 2 \mathrm{O}(\mathrm{mg} / 100 \mathrm{~g})$} & Between Groups & 27,556 & 2 & 13,778 & \multirow[t]{3}{*}{3,351} & \multirow[t]{3}{*}{,105 } \\
\hline & Within Groups & 24,667 & 6 & 4,111 & & \\
\hline & Total & 52,222 & 8 & & & \\
\hline \multirow[t]{2}{*}{$\mathrm{CaCO} 3$} & Between Groups & 1,313 & 2 & ,657 & \multirow[t]{2}{*}{72,148} & \multirow[t]{2}{*}{, 000} \\
\hline & Within Groups & 055 & 6 & ,009 & & \\
\hline
\end{tabular}




\begin{tabular}{|ll|r|r|r|r|r|} 
& Total & 1,368 & 8 & & \\
\hline T- S (meq /100g) & Between Groups & 27,042 & 2 & 13,521 & 52,453 &, 000 \\
& Within Groups & 1,547 & 6 &, 258 & & \\
& Total & 28,589 & 8 & & & \\
\hline
\end{tabular}

In the ANOVA analysis (table 3), the significance of the F-test show that there is a statistically significant difference at parameters $\mathrm{pH}_{\mathrm{H} 2 \mathrm{O}}, \mathrm{pH}_{\mathrm{KCl}}$, humus, $\mathrm{CaCO}_{3}$ and $\mathrm{T}-\mathrm{S}$ depending on dosages. In order to determine among which dosages there exist significant differences of these parameters, a LSD test was done.

Table 4. Multiple Comparisons - LSD test

\begin{tabular}{|c|c|c|c|c|c|c|c|}
\hline \multirow{2}{*}{ Dependent Variable } & \multirow{2}{*}{ (I) Dosage } & \multirow{2}{*}{ (J) Dosage } & \multirow{2}{*}{$\begin{array}{c}\text { Mean } \\
\text { Difference (I-J) }\end{array}$} & \multirow{2}{*}{ Std. Error } & \multirow{2}{*}{ Sig. } & \multicolumn{2}{|c|}{$95 \%$ Confidence Interval } \\
\hline & & & & & & Lower Bound & Upper Bound \\
\hline \multirow[t]{6}{*}{$\mathrm{pH}(\mathrm{H} 2 \mathrm{O})$} & dosage 1 & dosage 2 &,$- 53333^{*}$ &, 10184 &, 002 &,- 7825 &,- 2842 \\
\hline & & dosage 3 &,$- 80000^{*}$ &, 10184 &, 000 & $-1,0492$ &,- 5508 \\
\hline & dosage 2 & dosage 1 &, $53333^{*}$ &, 10184 &, 002 & ,2842 &, 7825 \\
\hline & & dosage 3 &,$- 26667^{*}$ & 10184 &, 040 &,- 5158 &,- 0175 \\
\hline & dosage 3 & dosage 1 &, $80000^{*}$ &, 10184 &, 000 &, 5508 & 1,0492 \\
\hline & & dosage 2 &, $26667^{*}$ & 10184 &, 040 &, 0175 & .5158 \\
\hline \multirow[t]{6}{*}{$\mathrm{pH}(\mathrm{KCl})$} & dosage 1 & dosage 2 &,$- 33333^{*}$ & ,09027 &, 010 &,- 5542 &,- 1125 \\
\hline & & dosage 3 &,$- 66667^{*}$ &, 09027 &, 000 &,- 8875 &,- 4458 \\
\hline & dosage 2 & dosage 1 & ,33333* & ,09027 &, 010 &, 1125 &, 5542 \\
\hline & & dosage 3 &,$- 33333^{*}$ &, 09027 &, 010 &,- 5542 &,- 1125 \\
\hline & dosage 3 & dosage 1 &, $66667^{*}$ & ,09027 &, 000 &, 4458 & ,8875 \\
\hline & & dosage 2 &, $33333^{*}$ &, 09027 &, 010 &, 1125 &, 5542 \\
\hline \multirow[t]{6}{*}{ Humus (\%) } & dosage 1 & dosage 2 &,- 30000 & , 14402 &, 082 &,- 6524 & ,0524 \\
\hline & & dosage 3 &,$- 46667^{*}$ &, 14402 &, 018 &,- 8191 &,- 1143 \\
\hline & dosage 2 & dosage 1 &, 30000 & , 14402 & ,082 &,- 0524 & ,6524 \\
\hline & & dosage 3 &,- 16667 &, 14402 & ,291 &,- 5191 & , 1857 \\
\hline & dosage 3 & dosage 1 & , 46667* &, 14402 &, 018 &, 1143 & 8191 \\
\hline & & dosage 2 &, 16667 &, 14402 & ,291 &,- 1857 & ,5191 \\
\hline \multirow[t]{6}{*}{$\mathrm{CaCO} 3$} & dosage 1 & dosage 2 &,$- 64333^{*}$ &, 07789 &, 000 &,- 8339 &,- 4527 \\
\hline & & dosage 3 &,$- 91000^{*}$ &, 07789 &, 000 & $-1,1006$ &,- 7194 \\
\hline & dosage 2 & dosage 1 & ,64333* & ,07789 &, 000 &, 4527 & ,8339 \\
\hline & & dosage 3 &,$- 26667^{*}$ &, 07789 &, 014 &,- 4573 &,- 0761 \\
\hline & dosage 3 & dosage 1 &, $91000^{*}$ &, 07789 &, 000 &, 7194 & 1,1006 \\
\hline & & dosage 2 & ,26667* &, 07789 &, 014 &, 0761 &, 4573 \\
\hline \multirow[t]{5}{*}{ T- S (meq /100g) } & dosage 1 & dosage 2 & $1,83333^{*}$ & ,41455 & ,004 &, 8190 & 2,8477 \\
\hline & & dosage 3 & $4,23333^{*}$ & .41455 &, 000 & 3,2190 & 5,2477 \\
\hline & dosage 2 & dosage 1 & $-1,83333^{*}$ & ,41455 &, 004 & $-2,8477$ &,- 8190 \\
\hline & & dosage 3 & $2,40000^{*}$ & ,41455 &, 001 & 1,3856 & 3,4144 \\
\hline & & dosage 1 & $-4,23333^{*}$ & ,41455 &, 000 & $-5,2477$ & $-3,2190$ \\
\hline
\end{tabular}




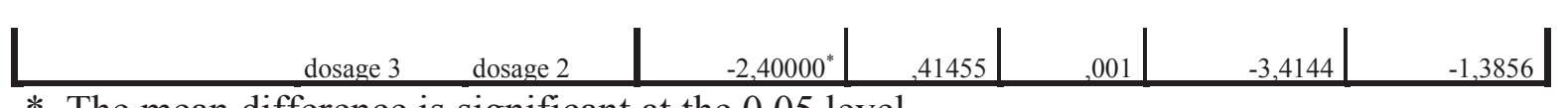

*. The mean difference is significant at the 0.05 level.

Based on this test it can be clearly concluded that the mean values of $\mathrm{pH}_{\mathrm{H} 2 \mathrm{O}}$, as well as the values of $\mathrm{pH}_{\mathrm{KCL}}$ are significantly different within all the dosages, while mean values of humus are significantly different only between the first and third dosage. But this fact does not influence the main goal of the research. Mean values of T-S are also statistically significant among all the applied dosages. This fact is important to the goal of this research.

Based on these results the melioration of Ranker soil type with EF ash from Kosovo's thermal power plants is obvious, and there has been a significant increase in $\mathrm{pH}$. Changing the chemical properties of Ranker enabled better nutritional utilization, better cultivation of the culture (grass mixtures), better quality of the product as well as higher yields.

\section{Conclusion}

The results of the study of the impact of EF ashes on the repair of Ranker soil type indicate that EF ash, from the point of view of its chemical properties, is a suitable material for the calcification of acidic soils of the ranker (humic-silicate) type. This is particularly conditioned by the high content of $\mathrm{CaO}$ in ash, as well as by absence $\mathrm{Na}^{+}$ions.

The performance of the EF ash provided better feedability of the nutrients, which significantly influenced the yield of cultivated culture.

\section{REFERENCES}

1. Resulović, H. I dr. (1991): Problems of soil degradation inYugoslavia. Zemljište i biljka 40, No. 3, Beograd

Black, C.A., Evans, D.D., Ehite, J.L., Ensimger, L.E., Clark, F.E. (1965): Methods of soil analyses, Agronomy, No. 9 part 2.

2. Banasova V. (1989): Relation of plant species to the $\mathrm{pH}$ of the soil -on mine heaps. Ecology (ČSSR) Vol. 8 No. 2, 117-122.

3. Cairney, T. (1987): Reclaiming contaminatedland, 1988, pp. 123-145, Glasgow. GB.

4. Flaig, W. (1971): Organic Compounds in Soil. Soil science 1971 No 1 vol III: 19-33

5. Šmit, S., Miletić, Z. (1998): The perspective of further works on re-cultivation by afforestation. Jubilee Scientific Conference with International Participation" 70th Anniversary of the Forest Research"' 6-7 October 1988, Sofia, pp. 136-139.

6. Djikic, A., Ilic, Z., Gudzic, N.: Influence of Fly-ash of Kosovo Thermoelectric powerplants on Properties of Soil Type Districh Cambisol, "Proceedings of the I Regional Symposium"Chemistry and Environment", pp. 691-694, Vrnjacka Banja, 1995.

7. Institut „Jaroslav Černi“, Pedološka karta SAP Kosova i Metohije 1:50000, Beograd, 1974. 